\title{
Assessment of the foliar micromorphology, phytochemical and mineral composition of Justicia secunda Valh leaves
}

Paul Oluwatimilehin Ogunbamowo, Musbau Bayonle Olaniyi, Olamilekan Lanre Awotedu \& Ibraheem Oduola Lawal

Biomedicinal Research Centre, Forestry Research Institute of Nigeria, Jericho hills, Ibadan, Oyo State. Nigeria.

Correspondence

PO. Ogunbamowo

E-mail: olutimmy7@gmail.com

Received: 18 March 2020

Accepted: 9 October 2020

Published on-line: 20 December 2020

\section{Resumen}

Evaluación de la micromorfología foliar, fitoquímica y composición mineral de las hojas de Justicia secunda Valh

Justicia secunda es una planta medicinal que pertenece a la familia Acanthaceae, es muy utilizada en la medicina tradicional para el tratamiento y manejo de una amplia gama de dolencias. En este estudio, la selección/análisis de fitoquímicos, minerales y características micro-morfológicas de las hojas de $J$. secunda se evaluaron utilizando procedimientos estándar. Los datos generados para el contenido fitomineral y fitoquímico de las hojas así como la prueba quimio-microscópica y los rasgos anatómicos foliares de las hojas que revelaron rasgos característicos distintos serán de utilidad en la sistemática, adecuada identificación, autenticación y estandarización de esta planta para fines medicinales propósitos.

Palabras clave: Quimio-microscopía; Justicia secunda; Fitominerales; Micromorfología; Fitoquímicos; Anatomía de la hoja.

\begin{abstract}
Justicia secunda is a medicinal plant that belongs to the family Acanthaceae, it is widely used in traditional medicine for the treatment and management of a wide range of ailments. In this study, the phytochemicals screening/analysis, minerals and micro-morphological characteristics of the leaves of J. secunda were evaluated using standard procedures. The data generated for the phytomineral and phytochemical contents of the leaves as well as the chemo-microscopic test and foliar anatomical features of the leaves which revealed distinct characteristic features will be useful in the systematics, proper identification, authentication and standardization of this plant for medicinal purposes.
\end{abstract}

Key words: Chemo-microscopy; Justicia secunda; Phytominerals; Micro-morphology; Phytochemicals; Leave anatomy. 


\section{Introduction}

Justicia secunda Vahl belongs to the family Acanthaceae, which is one of the many species of Justicia L. genus commonly used in African traditional medicine. J. secunda originated from South America, but has fully been domesticated in tropical regions of Africa including Nigeria (Koffi et al. 2013; Kitadi et al. 2019). It is a perennial herb that grows up to $90 \mathrm{~cm}$ with purplish green stem, evergreen leaves and pink flowers. It is an upright shrub that grows well in humid soils and colonies around river banks and creeks. J. secunda has simple leaves and the flowers are contained in terminal panicles (Heywood \& Moore 1978). It is commonly known as blood leaf or blood root in Barbados (Carrington et al. 2012). The leaf decoction is reportedly consumed in different regions of Africa including Nigeria for the management of anaemia (Mpiana et al. 2010a). The leaf decoction is known to produce a purplish/blood red colouration which may suggest why through the doctrine of signature the plant is used traditionally used as hematinic to boost the blood. Its aqueous decoction is normally served as a tea drink to anaemic patients in some communities. The activities of $J$. secunda plant parts such as the anti-sickling and hematinic have been demonstrated in previous studies (Mpiana et al. 2010a; Mpiana et al. 2010b; N'guessan et al. 2010; Kone et al. 2012). Various ethno-medicinal importance of this plant have been reported in studies seeking to provide scientific bases for the traditional uses of the plant. The potential of the plant in the treatment of diabetes mellitus was demonstrated through the isolation of alpha glucosidase inhibiting compounds from $J$. secunda leaves (Theiler et al. 2016), while its biological activity against certain gram positive bacteria were reported by Herrera-Mata et al. (2002). The antihypertensive activity (Manda et al. 2011), the hypoglycemic and anti-hyperglycemic effect (Mea et al. 2017) of the plant has been demonstrated in experimental animals, while the antioxidant, anti-inflammatory and antinociceptive activities have also been reported (Onoja et al. 2017). Most of these activities have been attributed to the bioactive substances present in the plant.

Although phytochemicals, also called secondary metabolites are naturally present in various parts of medicinal plants including $J$. secunda, they have protective mechanism and defend plants from various stress, they are non-nutritive compounds that are needed for sustaining life; they confer flavour, colour and protection to plants and humans (Agbafor \& Nwachukwu 2011). The foliar micro-morphological characters of medicinal plants offer an in-depth evidence to assist in the proper identification of a wide range of species; these features are vital taxonomic characters that help in minimising the misrepresentation and misidentification of medicinal plants. Hence, phytochemical analysis and micro-morphological evaluation are some of the ways medicinal plants utilized in traditional medicine are typically standardized and authenticated (Chanda 2014). In spite of the diverse range of chemical compounds reported in the leaves of some Justicia genus, little data is available on the basic chemical composition and foliar micro-morphology of the $J$. secunda. This information, together with studies on the epidermal features of the leaves is of significance in the proper identification and standardization during the evaluation of medicinal plants. The aim of this study was to evaluate the phytochemical profile, mineral composition, chemo-microscopic and micro-morphological features of the leaves of $J$. secunda.

\section{Materials and methods}

\section{Collection and preparation of plant materials}

Fresh leaf samples were harvested at the herbal garden of Forestry Research Institute of Nigeria (FRIN) $\quad\left(7^{\circ} 23^{\prime} 48.287 .5 \mathrm{~N}, 3^{\circ} 51^{\prime} 48.96 .0 \mathrm{E}\right)$. The leaves were identified and authenticated by a taxonomist at the Forest Herbarium Ibadan. The leaf samples for phytochemical determination, mineral estimation and chemo-microscopic examination were dried at room temperature for two weeks after which it was milled to powdered using a milling machine. The powdered sample was kept in an air tight container for further use.

\section{Phytochemical evaluation}

Qualitative screening and quantitative phytochemical analysis were done to identify and quantify the chemical components present in the leaves of $J$ secunda. The chemical components determined include: alkaloids, saponins, flavonoids, tannins, phenolic compounds, terpenoids, and cardiac glycosides. The phytochemical screening was evalu- 
ated using the standard procedures as described by Boye et al. (2012) and Omoruyi et al. (2012), while the quantitative analysis was done using the procedures described by Mbaebie et al. (2012).

In the qualitative test, frothing test was done to test the presence of saponins, the presence of tannins was ascertained using the ferric chloride test, flavonoids presence was tested using ethyl acetate and dilute ammonia, terpenoids were tested using chloroform and acetic anhydride test, alkaloids were tested using Dragendorff's, Mayer's and Wagner's reagent, while cardiac glycoside was tested using the Keller-Killani test. In the quantitative estimation, alkaloids were determined by gravimetry after extraction with $10 \%$ acetic acid in ethanol for 4 hours followed by precipitation using concentrated ammonium hydroxide, flavonoids were determined spectrophotometrically with aluminium chloride, saponins were determined by gravimetry after repeated extraction with $20 \%$ ethanol, followed by diethyl ether, and then butan-1-ol, tannins were determined spectrophotometrically using Folin-ciocalteu reagent with tannic acid standard, phenolic compounds were also determined similarly as tannin but using gallic acid standard while terpenoids was determined by gravimetry after extraction with ethanol followed by petroleum ether.

\section{Mineral evaluation}

Elemental analysis was done according to the method described by Isaac \& Korber, (1971). Powdered sample $(0.5 \mathrm{~g})$ was digested with a diacid mixture of $\mathrm{HNO}_{3}: \mathrm{HClO}_{4}(2: 1)$ after which the digest, adjusted to $50 \mathrm{~mL}$ mark was read on Atomic Absorption Spectrophotometer for all the mineral elements except sodium and potassium which were determined using a flame photometer.

\section{Chemo-microscopic evaluation}

Powdered samples of $J$. secunda leaves were cleared by soaking in hypochlorite solution, then pieces of the cleared samples was mounted on a new microscopic slide for each test, then detecting reagents for the detection of lipids ( 3 drops of sudan IV reagent was added), calcium oxalate (2 drops of dilute $\mathrm{HCl})$, lignin (2 drops of phloroglucinol followed by the addition of concentrated $\mathrm{HCl}$ ), mucilage (1 drop of ruthenium red was added to the sample on a microscope slide) and starch ( 2 drops of iodine was added to the sample on the slide) were added (Evans 2005).

\section{Leaf micro-morphology}

The micro-morphological features of the $J$. secunda leaves were evaluated by viewing the epidermal and transverse sections under a light microscope; the former was obtained by careful peeling of the abaxial and adaxial surfaces and the latter was obtained from the central vein using a microtome from matured fresh leaves of $J$. secunda. The epidermal sections obtained were cleared in sodium hypochlorite, washed in ethanol and then stained with safranine after which it was mounted in glycerine on a microscopic slide. The anatomical structures were viewed, analysed and photomicrographed using a light microscope (Amscope) (Verdam et al. 2012; Ohikhena et al. 2017).

\section{Results}

\section{Phytochemical Analysis}

The results of the phytochemical screening of the leaves of $J$. secunda confirmed the presence of a variety of secondary metabolites such as saponins, tannins, flavonoids, terpenoids, alkaloids and cardiac glycosides (Table 1).

The results of phytochemical composition confirmed that $J$. secunda leaves contain phytonutrients in varying amounts where tannin had the highest concentration followed by alkaloids and flavonoids was the lowest constituent (Table 2).

\begin{tabular}{|c|c|c|}
\hline Phytochemical Test & Observation & Leaves \\
\hline $\begin{array}{c}\text { Saponins } \\
\text { (Frothing test) }\end{array}$ & Persistence foaming & + \\
\hline $\begin{array}{c}\text { Tannins } \\
\text { (Ferric chloride) }\end{array}$ & $\begin{array}{l}\text { Greenish-brown } \\
\text { precipitate }\end{array}$ & + \\
\hline $\begin{array}{c}\text { Flavonoids } \\
\text { (Ethyl-acetate test) }\end{array}$ & Intense yellow colouration & + \\
\hline $\begin{array}{c}\text { Terpenoids } \\
\text { (Chloroform and acetic } \\
\text { anhydride test) } \\
\text { Alkaloid }\end{array}$ & A grey colouration & + \\
\hline $\begin{array}{l}\text {-Dragendorff's reagent } \\
\text { - Mayer's reagent }\end{array}$ & $\begin{array}{c}\text { Red precipitate } \\
\text { Creamy-white precipitate }\end{array}$ & $\begin{array}{l}+ \\
+\end{array}$ \\
\hline $\begin{array}{l}\text {-Wagners reagent } \\
\text { Cardiac Glycosides } \\
\text { (Sulphuric acid test) }\end{array}$ & $\begin{array}{l}\text { Reddish-brown precipitate } \\
\text { Brick-red precipitate }\end{array}$ & $\begin{array}{l}+ \\
+\end{array}$ \\
\hline
\end{tabular}

Tabla 1. Examen fitoquímico cualitativo de las hojas de $J$. secunda

Table 1. Qualitative phytochemical screening of the leaves of $J$. secunda. 


\begin{tabular}{cc}
\hline Phytochemical & Levels $(\mathbf{m g} / \mathbf{1 0 0} \mathbf{g})$ \\
\hline Alkaloids & $2040 \pm 210$ \\
Flavonoids & $130 \pm 80$ \\
Saponins & $760 \pm 162$ \\
Tannins & $2410 \pm 150$ \\
Phenols & $1652 \pm 10$ \\
Terpenoids & $980 \pm 112$ \\
\hline *values are presented as Mean \pm Standard deviation, $\mathrm{n}=3$
\end{tabular}

*values are presented as Mean \pm Standard deviation, $n=3$

Tabla 2. Análisis fitoquímico cuantitativo de hojas de J. secunda. Table 2. Quantitative phytochemical analysis J. secunda leaves.

\section{Mineral composition}

Results obtained for mineral analysis of the leaves of $J$. secunda revealed that macro-element ranged from $0.025 \%$ (phosphorus) to $2.48 \%$ (calcium) while the micro-elements ranged from $0.003 \%$ (copper) to $0.12 \%$ (iron) (Table 3 ).

\begin{tabular}{|c|c|}
\hline Minerals & Concentration (\%) \\
\hline \multicolumn{2}{|c|}{ Macro Elements } \\
\hline Sodium (Na) & $0.037 \pm 0.03$ \\
\hline Potassium (K) & $0.29 \pm 0.12$ \\
\hline Calcium (Ca) & $2.48 \pm 0.07$ \\
\hline Magnesium (Mg) & $0.41 \pm 0.02$ \\
\hline Phosphorus (P) & $0.025 \pm 0.023$ \\
\hline \multicolumn{2}{|c|}{ Micro Elements } \\
\hline Iron (Fe) & $0.12 \pm 0.02$ \\
\hline Manqanese $(\mathrm{Mn})$ & $0.005 \pm 0.00$ \\
\hline Copper (Cu) & $0.003 \pm 0.00$ \\
\hline Zinc $(\mathrm{Zn})$ & $0.03 \pm 0.01$ \\
\hline
\end{tabular}

${ }^{*}$ values are presented as Mean \pm s tandard deviation, $n=3$

Tabla 3. Composición mineral e hojas de $J$. secunda.

Table 3. Mineral composition of $J$. secunda leaves

\section{Chemo-microscopic properties}

The results of the chemo-microscopic analysis of the powdered leaf samples of $J$. secunda showed that calcium carbonate and starch were the only chemo compounds present in the powdered samples while other properties like lipids, calcium oxalate, lignin and mucilage were absent (Table 4).

\begin{tabular}{ccc}
\hline Property & Observation & Inference \\
\hline Lipids & No pink colouration seen & Absent \\
Calcium carbonate & Effervescent was observed & Present \\
Calcium oxalate & No effervescent observed & Absent \\
Lignin & No visible colour change & Absent \\
Mucilage & No pink colouration & Absent \\
Starch & Blue-black colouration & Present \\
\hline
\end{tabular}

Tabla 4. Propiedades quimio-microscópicas de hojas pulverizadas de $J$. secunda.

Table 4. Chemo-microscopic properties of J. secunda leaf powder.

\section{Leaf micro-morphology}

Results of the microscopic examination of the epidermal sections of $J$. secunda leaves as summarized in the table 5 shows that the shape of the epidermal cells are irregular, with anticlinal walls that are sinuate in both the abaxial and adaxial epidermis, also possessing non-glandular trichomes which are bristle-like and hairy that are also densely distributed in both upper and lower epidermis (Figs. 1A-D), the mean cell length was determined to be 26.95 and $25.21 \mu \mathrm{m}$, cell width (20.11 and $16.91 \mu \mathrm{m})$ and cell density (108.10 and $210.60 \mu \mathrm{m}$ ) for the abaxial and adaxial epidermis respectively. Meanwhile, the epidermis was also characterized by anomocytic stomata, with the stomata length, width, index and density were found to be $19.67 \mu \mathrm{m}, 13.61 \mu \mathrm{m}, 47.53 \%$ and 98.65 for the abaxial epidermal surface respectively. The transverse section of the leaves is characterized by presence of the lower and upper epidermis, as well as the parenchyma cells, collenchyma cells, vascular bundles among the other common features (Fig. 2).

\begin{tabular}{ccc}
\hline $\begin{array}{c}\text { Epidermal } \\
\text { Characteristics }\end{array}$ & Abaxial & Adaxial \\
\hline Cell shape & Irregular & Irregular \\
Anticlinal walls & Sinuate & Sinuate \\
Cuticle & Present & Nil \\
Cell length $(\mu \mathrm{m})$ & $26.95 \pm 3.57$ & $25.21 \pm 4.67$ \\
Cell width $(\mu \mathrm{m})$ & $20.11 \pm 2.40$ & $16.91 \pm 3.04$ \\
Cell density & $108.10 \pm 4.38$ & $210.60 \pm 6.58$ \\
Stomata type & Anomocytic & Anomocytic \\
Stomata length $(\mu \mathrm{m})$ & $19.67 \pm 2.47$ & - \\
Stomata width $(\mu \mathrm{m})$ & $13.61 \pm 1.71$ & - \\
Stomata index $(\%)$ & $47.53 \pm 1.43$ & $17.33 \pm 2.09$ \\
Stomata density & $98.65 \pm 4.04$ & $34.24 \pm 2.02$ \\
Trichomes & Non-glandular hairs & Non-glandular \\
& & hairs \\
\hline
\end{tabular}

*values are presented as Mean \pm standard deviation, $\mathrm{n}=20$ Tabla 5. Características epidérmicas de las hojas de J. secunda. Table 5. Epidermal features of $J$. secunda leaves.

\section{Discussion}

Results from this study revealed the presence of all the phytochemicals tested, this observation was similarly reported in earlier studies on various extracts of $J$. secunda leaves from different locations (Mora \& Pesantes 2017, Osioma \& HamiltonAmachree 2017; Nnadozie et al. 2019) likewise, in other closely related species like Justicia carnea Lindl. (Onyeabo et al. 2017). The quantitative phytochemical composition of $J$. secunda leaves showed different levels of the measured 


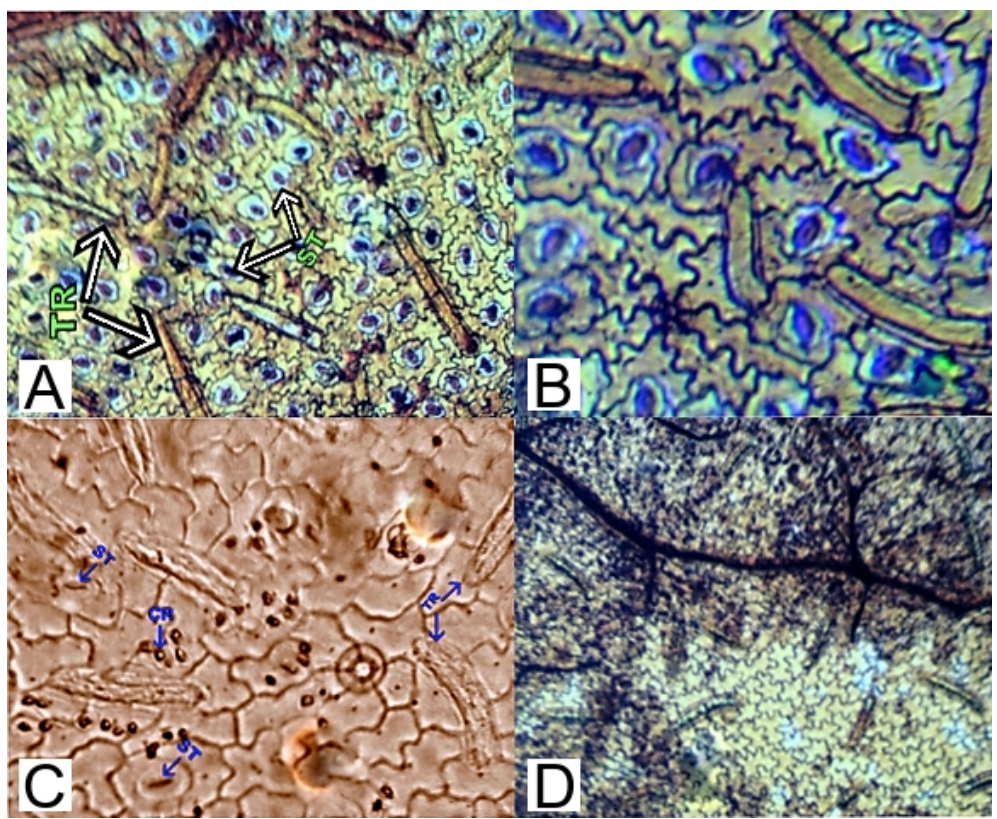

Figura 1. Fotomicrografías de secciones epidérmicas de hojas de $J$. secunda. A: superficie abaxial (x5); B: Superficie abaxial (x10); C: superficie adaxial (x10); C: superficie adaxial (x5). ST: estoma, TR: tricoma, CR: cristales.

Figure 1. Photomicrographs of epidermal sections of $J$. secunda leaves. A: abaxial surface (x5); B: abaxial surface (x10); C: adaxial surface (x10); D: adaxial surface (x5). ST: stomata, TR: trichome, CR: crystals.

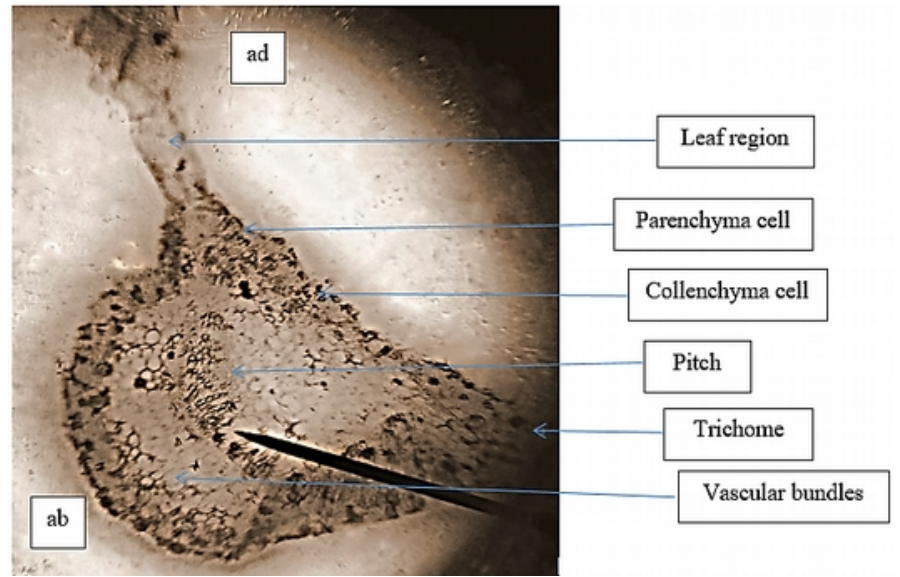

Figura 2. Fotomicrografía de la sección trasversal hoja de $J$. secunda, mostrando la zona de la hoja, la pared celular, los haces vasculares, las células del colénquima y parénquima y la resina (x10).

Figure 2: Photomicrograph of transverse section of $J$. secunda leaf showing the leaf region, cell wall, vascular bundle, collenchyma and parenchyma cells and pitch (x10).

substances which are quite within the range similarly reported for $J$. secunda leaves (Nnadozie et al. 2019), this in essence shows the richness of the plant in important secondary metabolites that are responsible for the traditional medicinal effects. Phytochemicals, also referred to as secondary metabolites that are naturally present in plants are known to be responsible for the medicinal effect they produce when utilized as herbal drugs. Many studies have suggested that phytochemicals possess pharmacological activities that can reduce or prevent the risk of diverse human diseases (Zhang et al. 2015, Shuruq et al. 2017, Forni et al. 2019). They help in the development of many therapeutic drugs that are utilized in the treatment and management of various diseases. Mostly, these plant chemicals are developed innately by plants to protect themselves against external hazards build-up in different parts of the plant parts, including leaves, roots, stem, bark, fruits and seeds (Costa et al. 1999, Zulak et al. 2006). Thus, J. secunda could serve as a rich source of phytochemicals such as alkaloids and tannins which are present in higher quantity in the plant. Alkaloids for in- 
stance, have been reported to have a wide range of pharmacological effects including microbiocidal effect, analgesic, sedatives, antimalarial activity, antioxidant and anti-inflammatory activities (Alves de Almeida et al. 2017, Bribi 2018). Furthermore, the presence of tannins in medicinal plant suggests the ability of these plants to play major therapeutic roles some of which are constantly being identified (Yildirim \& Kutlu 2015, $\mathrm{Vu}$ et al. 2017). Overall, all these phytochemicals have been reported for various pharmacological and therapeutic actions in various models. The biological activities of saponins (Yildirım \& Kutlu 2015, Desai et al. 2009), flavonoids (Kumar \& Pandey 2013, Agrawal 2011), cardiac glycosides (Morsy 2017, Schneider et al. 2018), and terpenoids are widely documented. The presence of these phytochemicals in $J$. secunda therefore, justifies its popularity as a very potent plant that could be used in the treatment and prevention of various diseases.

In addition, another important class of plant chemicals are minerals which play vital roles in nutrition and health (Soetan et al. 2010) and by virtue of the fact that most living organisms cannot synthesized them naturally, they need to be sourced for externally, most importantly through plants. However, it is also commonly known that minerals sourced from different plants also varies widely from various places, as a result, investigations on the mineral composition of different medicinal plants continue to provide much needed information on the mineral status of such plants and could also explain some of the pharmacological responses attributed to it. This study provides information on some mineral content in $J$. secunda leaves. The results of the mineral composition of $J$. secunda leaves revealed that among the macro elements determined, the leaves contain high concentration of calcium $(2.48 \%)$, which suggests that it could be a good source of calcium. Calcium is one of the essential minerals for human health. It plays active roles in the biological functions of many tissues, while also serving as cofactors in several enzyme reactions and the maintenance of homeostasis (Martínez-Ballesta et al. 2010). Higher concentration of calcium was previously reported in aqueous extracts of $J$. carnea leaves (Orjiakor et al. 2019) which may suggest an inherent property of the Justicia genus. The concentration of calcium in the leaves of $J$. secunda as determined in this study was found to be significantly higher than the levels reported for other similarly useful medicinal plants such as Parquetina nigrescens (Afzel.) Bullock (Kayode \& Yakubu 2017; Odukoya et al. 2018), Launaea taraxacifolia (Willd.) Amin ex C.Jeffrey, Solanum americanum Mill. (as Solanum nigrun L.) (Odukoya et al. 2018) and Crescentia cujete L. (Olaniyi et al. 2018). However, higher calcium concentration was reported in Azadirachta indica A.Juss., Parkia biglobosa (Jacq.) G.Don and Leea guineensis G. Don (Awotedu et al. 2019) compared with the levels determined in this study. Moreover, phosphorus was found to have the lowest value $(0.025 \%)$ for macro elements. This concentration is comparable with that reported for $P$. nigrescens (Kayode \& Yakubu 2017) a medicinal plant also used to improve blood parameters. Phosphorus is reported to be present in edible vegetables in the region of $0.016-0.437 \%$ and like calcium, phosphorus is interconnected in the maintenance of acid-base balance and the formation of strong bones and teeth (Martínez-Ballesta et al. 2010). Phosphorus is also vital component of energy rich substances such as adenosine triphosphate (ATP), nucleic acids and many coenzymes (Soetan et al. 2010; Martínez-Ballesta et al. 2010). Other macro mineral contents of the leaves of $J$. secunda are consistent with the diverse range generally observed in different plants; for instance, the ratio of sodium to potassium intake has continuously been linked to either higher or lower risk of hypertension and blood pressure, with lower ratio favouring lower risk of blood pressure and hypertension (Perez \& Chang 2014; Iwahori et al. 2017; Park et al. 2016). The ratio of $\mathrm{Na}: \mathrm{K}$ in $J$. secunda (calculated to be 0.13 ) is therefore, in conformity with this requirement which suggest that the plant could supply both mineral in the required ratio to minimize the risk of high blood pressure and hypertension. The micro mineral trend in the leaves of $J$. secunda also revealed that, iron had the highest concentrations, a much lower iron and zinc concentration was reported in the aqueous leave extracts of Justicia carnea while copper concentration was found to be comparable in same plants (Orjiakor et al. 2019).

In spite of the beneficial effect of herbal plants in traditional medicine, one major drawback is the misidentification and mistaken substitution of the medicinal plant with closely related species which may lead to the problem of adulteration of the 
herbal product (Sharaibi \& Afolayan 2017). Apart from the key roles of morphological characters' assessment in plant taxonomy, studies on the foliar micromorphology of medicinal plants are also important in establishing standards for identifying adulterated medicinal plants. Consequently, the evaluation of the leaf powdered sample's micromorphology provide a cost effective means in the identification, safety assessment and authentication of original medicinal plant from crude drug materials (Shekhawat \& Manokari 2017; Lawal et al. 2018). Results from the microscopic evaluation of the powdered sample of $\mathrm{J}$. secunda indicated the presence of starch granules which was further confirmed in the chemo-microscopic test while calcium carbonate was also detected during the chemical test. The epidermal features as obtained from the light microscope photomicrographs shows that the leaf of the plant is amphistomatic with stomata type identified as anomocytic, which is more concentrated in the abaxial surface. This implies efficient exchange of gases at both surfaces of the leaves of $J$. secunda which is in consonance with what was earlier reported for $J$. carnea which has been observed to be amphistomatic (Nduche \& Offor 2019). This could suggest that both species are closely related.

The shape of the epidermal cells is notably irregular, polygonal, undulating, and the anticlinal walls patterns are sinuate in both upper and lower epidermis as observed by visual comparison with similar sinuate anticlinal walls observed in the study by Cheng (2006). Cuticles which are characterized by cuticular intrusions either identified as ' $\mathrm{T}$ ' bits or rod/bar located between the ends of each guard cell (Cheng 2006) are present. Trichomes are tiny outgrowths that can be found in plant epidermis. Some trichome types such as the glandular trichomes are known to be specialized secretory structures that perform different functions in different plant species (Robles-Zepeda et al. 2009). Non-glandular trichomes are densely distributed in both the upper and lower epidermis of the leaves of $J$. secunda, these trichomes are unicellular possessing fine-curved tips and broad base, characteristics that were also observed and reported in Cardiospermum halicacabum L., a medicinal climber (Shekhawat \& Manokari 2017), likewise, study by Cassola et al. (2019) revealed the presence of both glandular and non-glandular type of trichomes in three species of Justicia ( Justicia brandegeeana Wassh. \& L.B.Sm., Justi- cia gendarussa Burm.f. and Justicia pectoralis Jacq.) from Brazil, where the presence of phytochemicals like flavonoid was observed in the glandular trichome. The high density of this trichome type in both surfaces may be useful in reducing the transpiration rate in the plant. So, the densely packed non-glandular trichomes noted in this study may offer taxonomic information which could be peculiar to this Justicia species thus, highlighting its importance as a diagnostic tool in taxonomy (Adeniji and Ariwaodo, 2012; Sonibare et al. 2014). The transverse section of the leaves is characterized by different cells arranged in typical manners serving diverse functions such as the parenchyma cells, collenchyma cells, vascular bundles among the other common features. Overall, these features are useful in establishing standards for ensuring the quality and safety of medicinal plants.

It could be deduced from this study that the medicinal attributes of $J$. secunda as evident from ethnobotanical and folkloric uses may be attributed to the presence of the secondary metabolites. Accordingly, J. secunda is a rich source of phytochemicals and minerals which in no small measure might help in the treatment, prevention and management of diverse medical complications. The foliar anatomical features of the leaves also revealed some micromorphological characters identified as: amphistomatic leaves, anomocytic stomata, irregularly shaped epidermal cells, sinuate patterned anticlinal walls and dense concentration of non-glandular trichomes in both upper and lower epidermal surfaces; chemo-microscopic test reveals the presence of starch and calcium carbonate. These features could be useful in the systematics, proper identification, standardization and ultimately contribute to the development of African pharmacopoeia.

\section{Acknowledgments}

The authors appreciate the contributions of $\mathrm{Mr}$. Adeniyi of the FPD\&U department and Herbal garden team, Biomedicinal Research Centre, Forestry Research Institute of Nigeria.

\section{References}

Adeniji KA \& Ariwaodo JO. 2012. Comparative foliar epidermal studies of genus pericopsis (Papilionaceae) in Nigeria. Phytol Balcanica 18(1): 37-41. 
Agbafor KN \& Nwachukwu N. 2011. Phytochemical analysis and antioxidant property of extracts of Vitex doniana and Mucuna pruriens. Biochemical Research International 10: 1155-1159. https://doi.org/ 10.1155/2011/459839

Agrawal A. 2011. Pharmacological activities of flavonoids: a review. International Journal of Pharmaceutical Science and Nanotechnology 4(2): 1394-1398. https://doi.org/10.37285/ijpsn.2011.4.2.3

Alves de Almeida AC, Meira de-Faria F, Dunder RJ, Manzo LPB, Souza-Brito ARM \& Luiz-Ferreira A. 2017. Recent trends in pharmacological activity of alkaloids in animal colitis: potential use for inflammatory bowel disease. Evidence-Based Complementary and Alternative Medicine 2017: 8528210 [24]. https://doi.org/10.1155/2017/8528210

Awotedu OL, Ogunbamowo PO, Emmanuel IB \& Lawal IO. 2019. Phytominerals and phytochemical studies of Azadiracthta indica, Leea guineensis and Parkia biglobosa Leaves. International Annals of Science 6(1): 28- 34. https://doi.org/10.21467/ias.6.1.28-34

Boye AG, Koffuor GA, Boampong JN, Amoateng PA, Ameyaw EO, Ansah EO, ... Penu DKA. 2012. Gastroprotective effect and safety assessment of Zanthoxylum zanthoxyloides (Lam) waterm root bark extract. American Journal of Pharmacology and Toxicology 7(2): 73-80. https://doi.org/10.3844/ajptsp. 2012.73.80

Bribi N. 2018. Pharmacological activity of alkaloids: a review. Asian Journal of Botany 1: [6] https://doi.org/ 10.63019/ajb.v1i2.467

Carrington S, Cohall DH, Gossell-Williams M, Lindo JF. 2012. The antimicrobial screening of a Barbadian medicinal plant with indications for use in the treatment of diabetic wound infections. West Indian Medical Journal 61(9):861-864. https://doi.org/10.7727/ wimj.2011.223.

Cassola F, Reis da Silva, MH, Borghi AA, Lusa MG, Sawaya ACHF, Garcia VL \& Mayer JLS. 2019. Morphoanatomical characteristics, chemical profiles, and antioxidant activity of three species of Justicia L. (Acanthaceae) under different growth conditions. Industrial Crops \& Products 131: 57-265. https://doi. org/10.1016/j.indcrop.2019.01.053

Chanda S. 2014. Importance of pharmacognostic study of medicinal plants. An overview. Journal of Pharmacognosy and Phytochemistry 2: 69-73.

Cheng QA. 2006. Morphological characters of leaf epidermis in Schisandraceae and their systematic significance. Journal of Plant Biology 49(1): 80-87. https://doi.org/10.1007/BF03030791

Costa MA, Zhi-Qiang X, Davin LB \& Lewis NG. 1999. Toward engineering the metabolic pathways of cancer-preventing lignans in cereal grains and other crops. In: Phytochemicals in human health protection, nutrition, and plant defense. In Phytochemicals in Human Health Protection, Nutrition, and Plant Defense (Romeo JT, eds) (Proceedings of the Phytochemical Society of North America, vol 33). Boston, MA: Springer, p 67-87. https://doi.org/10.1007/9781-4615-4689-4_4

Desai SD, Desai DG \& Kaur H. 2009. Saponins and their biological activities. Pharma Times 41(3): 13-
16.

Evans WC. 2005. Trease \& Evans' Pharmacognosy. Delhi, India: Rajkamal Electric Press.

Forni C, Facchiano F, Bartoli M, Pieretti S, Facchiano A, D'Arcangelo D, ... Jadeja RN. 2019. Beneficial role of phytochemicals on oxidative stress and age-related diseases. BioMed Research International 2019: 8748253. http://dx.doi.org/10.1155/2019/8748 $\underline{253}$

Herrera-Mata H, Rosas-Romero A \& Oscar Crescente V. 2002. Biological activity of "Sanguinaria" (Justicia secunda) extracts. Pharmaceutical Biology 40(3): 206-212. http://dx.doi.org/10.1076/phbi.40.3.206.58 26

Heywood VH \& Moore DM. 1978. Flowering plants of the world. Oxford, England: Oxford University Press.

Isaac AR \& Korber JD. 1971. Atomic absorption and flame photometry technique and uses in soil, plant and water analysis. In Instrumental methods for analysis of soils, and plant tissues (Walsh LM, ed). Soil Science Society America Incorporation Wisconsin USA, p. 17-33. https://doi.org/10.2136/1971.instru mentalmethods.c2

Iwahori T, Miura K \& Ueshima H. 2017. Time to consider use of the sodium-to-potassium ratio for practical sodium reduction and potassium increase. Nutrients 9(7): 700. https://doi.org/10.3390/nu9070700

Kayode OT \& Yakubu MT. 2017. Parquetina nigrescens leaves: chemical profile and influence on the physical and biochemical indices of sexual activity of male wistar rats. Journal of Integrative Medicine 15(1): 64-76.

Kitadi JM, Lengbiye EM, Gbolo BZ, Inkoto CL, Muanyishay CL, Lufuluabo GL, . . . Mpiana PT. 2019. Justicia secunda Vahl species: Phytochemistry, pharmacology and future directions: a mini-review. Discovery Phytomedicine 6(4): 157-171. http://dx. doi.org/10.15562/phytomedicine.2019.93.

Koffi EN, Le Guernevé C, Lozano PR, Meudec E, djé FAA, Bekro YA \& Lozano YF. 2013. Polyphenol extraction and characterization of Justicia secunda Vahl leaves for traditional medicinal uses. Industrial Crop Production 49: 682-689. https://doi.org/10. 1016/j.indcrop.2013.06.001

Kone WM, Koffi AG, Bomisso EL \& Tra Bi FH. 2012. Ethnomedical study and iron content of some medicinal herbs used in traditional medicine in Cote D'ivoire for the treatment of anaemia. African Journal of Traditional and Complementary Alternative Medicine 9(1): 81-87. https://doi.org/10.4314/ajtcam.v9i1. 12

Kumar S \& Pandey AK. 2013. Chemistry and biological activities of flavonoids: an overview. The Scientific World Journal 2013: 162750 [16] https://doi.org/10. $1155 / 2013 / 162750$

Lawal IO, Uzokwe VNE, Rafiu B, \& Afolayan AJ. 2018. Foliar anatomy of Clausena anisata (Willd.) Hook: A South African medicinal plant. Nigerian Journal of Natural Product and Medicine 22(1): 149-154. https://doi.org/10.4314/njnpm.v22i1.8

Manda P, Abrogoua DP, Bahi C, Dano DS, Gnahoui G \& Kablan BJ. 2011. Evaluation of the antihypertensive 
activity of total aqueous extract of Justicia secunda Valh (Acanthaceae). African Journal of Pharmacy and Pharmacology 5(16): 1838-1845. http://dx.doi. org/10.5897/AJPP11.131

Martínez-Ballesta MC, Dominguez-Perles R, Moreno DA, Muries B, Alcaraz-López C, Bastias E, . . . Carvajal M. 2010. Minerals in plant food: effect of agricultural practices and role in human health. a review. Agronomy for Sustainable Development 30(2): 295-309. https://doi.org/10.1051/agro/2009022

Mbaebie BO, Edeoga HO \& Afolayan AJ. 2012. Phytochemical analysis and antioxidants activities of aqueous of stem bark extract of Schotia latifolia Jacq. Asian Pacific Journal of Tropical Biomedicine, 2(2): 118-124. https://doi.org/10.1016/S2221-1691 (11)60204-9

Mea A, Ekissi YHR, Abo KJC, \& Kahou Bi GP. 2017. Hypoglycaemiant and anti-hyperglycaemiant effect of Juscticia secunda M. Vahl (Acanthaceae) on glycaemia in the wistar rat. International Journal of Development Research 7(6): 13178-13184.

Mora PZ \& Pesantes KEB. 2017. Characterization and phytochemical study of Justicia secunda Valh (Sanguinaria, singamochilla, Insulina). Revista Cubana de Plantas Medicinales 22(1): 1-8

Morsy N. 2017. Cardiac glycosides in medicinal plants. In. Aromatic and medicinal plants - back to nature (El-Shemy HA, ed). IntechOpen. https://doi.org/ $10.5772 / 65963$

Mpiana PT, Bokota MT, Ndjele MBL, Mudogo V, Tshibangu DST, Ngbolua KN, ... Makelele LK. 2010. Antisickling activity of three species of Justicia from Kisangani (DR Congo): J. tenella, J. gendarussa and $\mathrm{J}$. insularis. International Journal of Biological and Chemical Sciences 4(6): 1953-1961. https://doi.org/ 10.4314/ijbcs. v4i6.64984

Mpiana PT, Ngbolua KNN, Bokota MT, Kasonga TK, Atibu EK, Tshibangu DST \& Mudogo V. 2010. In Vitro effects of anthocyanin extracts from Justicia secunda Vahl on the solubility of haemoglobin $S$ and membrane stability of sickle erythrocytes. Blood Transfusion 8: 248-254. http://dx.doi.org/10.2450/20 $\underline{09.0120-09}$

N'guessan K, Kouassi KH \& Ouattara D. 2010. Plants used to treat anaemia, in traditional medicine, by Abbey and Krobou populations, in the South of Coted'Ivoire. Journal of Applied Science Research 2010(6): 1291-1297.

Nduche MU \& Offor IC. 2019. Anatomical studies of Sida acuta Burm, Spigelia anthelmia Linn, Centrosema pubescens Benth, Pueraria phaseoloides (ROXB) Benth, Justicia carnea Lindl and their taxonomic significance. International Journal of Research in Pharmacy and Biosciences 6(2): 21-32.

Nnadozie C, Onwusonye JC, Odu DA, Ononogbo CN \& Ogbonna JO. 2019. Phytochemical studies and activities of leaf extracts of Justicia secunda and Persea americana against selected clinical microbial isolates. World Journal of Pharmaceutical Research 8(12): 1301-1310.

Odukoya JO, Odukoya JA \& Oshodi AA. 2018. Evaluation of the nutritional qualities of the leaves of Par- quetina nigrescens, Launaea taraxacifolia and Solanum nigrum. European Journal of Pure and Applied Chemistry 5(1): 18-31.

Ohikhena FU, Wintola OA \& Afolayan AJ. 2017. Micromorphological studies of the Loranthaceae, Phragmanthera capitata (Sprengel) Balle. Journal of Botany 2017: 5603140 [9]. https://doi.org/10.1155/201 7/5603140

Olaniyi MB, Lawal IO, \& Olaniyi AA. 2018. Proximate, phytochemical screening and mineral analysis of Crescentia cujete L. leaves. Journal of Medicinal Plants for Economic Development 2(1): a28 [7]. https://doi.org/10.4102/jomped.v2i1.28

Omoruyi BE, Bradley G \& Afolayan AJ. 2012. Antioxidant and phytochemical properties of Carpobrotus edulis (L.) bolus leaf used for the management of common infections in HIVIAIDS patients in Eastern Cape province. BMC Complementary and Alternative Medicine, 12: 215 [9]. https://doi.org/10.1186/ 1472-6882-12-215

Onoja SO, Ezeja MI, Omeh YN \& Onwukwe BC. 2017. Antioxidant, anti-inflammatory and antinociceptive activities of methanolic extract of Justicia secunda Vahl leaf. Alexandria Journal of Medicine 53: 207213. https://doi.org/10.1016/j.ajme.2016.06.001

Onyeabo C, Achi NK, Ekeleme-Egedigwe CA, Ebere CU \& Okoro CK. 2017. Haematological and biochemical studies on Justicia carnea leaves extract in phenylhydrazine induced-anemia in albino rats. Acta Scientiarum Polonorum Technologia Alimentaria 16(2): 217-230. http://dx.doi.org/10.17306/J.AFS.2017.04 $\underline{92}$

Orjiakor CA, Uroko RI, Njoku OU \& Ezeanyika LUS. 2019. Nutritive properties of aqueous extract Justicia carnea leaves and its effects on haematological and some biochemical indices of anaemia induced male wistar albino rats. Biomedical Research 30(4): 645654. https://doi.org/10.35841/biomedicalresearch.3 0-18-666

Osioma E \& Hamilton-Amachree A. 2017. Comparative study on the phytochemical and in-vitro antioxidant properties of methanolic leaf extract of Justicia secunda Vahl. Nigerian Journal of Science and Environment 15(1): 111-117.

Park J, Kwock CK \& Yang YJ. 2016. The effect of the sodium to potassium ratio on hypertension prevalence: a propensity score matching approach. Nutrients 8(8): 482. https://doi.org/10.3390/nu8080482

Perez V \& Chang ET. 2014. Sodium-to-potassium ratio and blood pressure, hypertension, and related factors. Advances in Nutrition 5(6): 712-741. https:// doi.org/10.3945/an.114.006783

Robles-Zepeda RE, Lozoya-Gloria E, Lopez MG, Villarreal ML, Ramırez-Chavez E \& Molina-Torres J. 2009. Montanoa tomentosa glandular trichomes containing kaurenoic acids chemical profile and distribution. Fitoterapia 80(1): 12-17 https:// doi.org/10. 1016/j.fitote.2008.09.002

Schneider NFZ, Cerella C, Lee J, Mazumder A, Kim KR, de Carvalho A, ... Diederich M. 2018. Cardiac glycoside glucoevatromonoside induces cancer typespecific cell death. Frontiers in Pharmacology 9: 70. https://doi.org/10.3389/fphar.2018.00070 
Sharaibi, JO \& Afolayan AJ. 2017. Micromorphological characterization of the leaf and rhizome of Agapanthus praecox subsp. praecox Willd. (Amaryllidaceae). Journal of Botany 2017: 3075638 [11]. https://doi.org/10.1155/2017/3075638

Shekhawat MS \& Manokari M. 2017. Foliar micromorphological evaluation of Cardiospermum halicacabum L. - an important medicinal climber. The Open Plant Science Journal 10: 1-9. https://doi.org/ 10.2174/1874294701710010001

Shuruq A, Noura A, Ghada A, Ghadeer A, Kavita MS, Maha AT \& Nesrine AH. 2017. Role of phytochemicals in health and nutrition. BAOJ Nutrition 3: 028.

Soetan KO, Olaiya CO \& Oyewole OE. 2010. The importance of mineral elements for humans, domestic animals and plants: a review. African Journal of Food Science 4(5): 200-222.

Sonibare MA, Oke TA \& Soladoye MO. 2014. A pharmacobotanical study of two medicinal species of Fabaceae. Asian Pacific Journal of Tropical Biomedicine 4(2): 131-136. https://doi.org/10.1016/S22211691(14)60221-5

Theiler BA, Istvanits S, Zehl M, Marcourt L, Urban E, Caisa LOE \& GlasI S. 2016. HPTLC Bioautography guided isolation of $\alpha$-glucosidase inhibiting compounds from Justicia secunda Vahl (Acanthaceae). Phytochemical Analysis. http://dx.doi.org/10.1002/ pca.2651
Verdam MCS, Ohana DT, Araujo MGP, Guilhon-Simplicio F, Sílvia de Mendonça M \& Pereira MM. 2012. Morphology and anatomy of Justicia acuminatissima leaves. Revista Brasileira de Farmacognosia Brazilian Journal of Pharmacognosy 22(6): 12121218. http://dx.doi.org/10.1590/S0102-695X201200 $\underline{5000129}$

Vu TT, Kim H, Tran VK, Vu HD, Hoang TX, Han JW, . . Kim JC. 2017. antibacterial activity of tannins isolated from Sapium baccatum extract and use for control of tomato bacterial wilt. PLoS ONE 12(7): e0181499. https://doi.org/10.1371/journal.pone. 018 1499

Yildirım I \& Kutlu T. 2015. Anticancer agents: saponin and tannin. International Journal of Biological Chemistry 9: 332-340. https://doi.org/10.3923/ijbc.2015.3 $\underline{32.340}$

Zhang Y, Gan R, Li S, Zhou Y, Li A, Xu D \& Li H. 2015. Antioxidant phytochemicals for the prevention and treatment of chronic diseases. Molecules 20(12): 21138-21156. http://dx.doi.org/10.3390/molecules2 $\underline{01219753}$

Zulak KG, Liscombe DK, Ashihara H \& Facchini PJ. 2006. Alkaloids, In: Plant secondary metabolites: occurrence, structure and role in the human diet (Crozier A, Clifford MN \& Ashihara H, eds). Oxford, UK: Wiley-Blackwell Publishing Limited, pp. 102136. 